\title{
Untapped Research Capacities? Mobility and Collaboration at the Intersection of International Development Aid and Global Science Regimes
}

\author{
Måns Fellesson and Paula Mählck
}

\begin{abstract}
:
This article aims to offer some thoughts that go beyond mere bibliometric and scientometric evidence, by empirically and comparatively exploring the conditions for, and the experiences of research and international research collaboration of African PhD holders who graduated with support from development cooperation/aid. The article explores the constraints on research, international research mobility and collaboration, at the intersection of development cooperation and global science regimes. Taking Swedish development cooperation as an example, the article focuses on preconditions and constraints that scholars from Mozambique and Tanzania, in their current positions, experience in their research, with special attention on international mobility and cooperation.
\end{abstract}

Cet article a pour objectif de proposer des réflexions qui dépassent les simples preuves bibliométriques et scientométriques, en explorant empiriquement et comparativement les expériences de recherche et de collaborations scientifiques internationales de docteurs africains ayant reçu une aide au développement pour leur doctorat. Cet article explore les limites auxquelles se heurtent la recherche, la mobilité internationale et la coopération scientifique internationale, à l'intersection entre la coopération au développement et les programmes scientifiques mondiaux. En prenant pour exemple la coopération au développement suédoise, cet

ABOUt THE AUthors: MÅNS FELLESSON is a deputy director at the Global Agenda Department in the Swedish Ministry for Foreign Affairs. E-mail: mans.fellesson@gov.se.

PAULA MÄHLCK is a senior researcher and lecturer at the Department of Education, Stockholm University, Sweden. E-mail: paula.mahlck@edu.su.se. 
article se focalise sur les conditions et les contraintes que les académiques du Mozambique et de Tanzanie, au sein de leur emploi actuel, rencontrent dans le cadre de leur recherche, en portant une attention particulière sur la mobilité internationale et la coopération.

\section{Introduction}

This article explores constraints on research, international research mobility and collaboration, at the intersection of development cooperation and global science regimes. Taking Swedish development cooperation as an example, the article focuses on preconditions and constraints that scholars from Mozambique and Tanzania, in their current positions, experience in their research, with special attention on international mobility and cooperation.

Since the I970s, Swedish development cooperation for research has pioneered a particular approach to institutional research capacity building, by focusing on research training as a prime component to achieve competitive and sustainable research environments at national universities in collaborating African countries (Sida' 2003). According to the so-called 'sandwich model'-designed to help scholars maintain links with their home institutions during training-mobility and collaboration are placed at the core of knowledge transfer from universities in Sweden to their African counterparts; gradually, this is to result in enhanced international collaboration and the establishment of local PhD training programmes. In Mozambique and Tanzania, these programmes have been in operation for over 35 years, and a considerable number of $\mathrm{PhD}$ graduates have been trained within the framework of a fairly steady constellation of institutional collaboration (Sida 2003; 2010). Over the years, confidence in the model has been so high that it has overshadowed the need to examine the longterm effects of the support, in terms of frequency, patterns and conditions for mobility and collaboration among the participating researchers, and in terms of how-and to what extent-these effects are linked to structures of inequality in the relationship with international, non-African researchers and institutions (Fellesson and Mählck 2013).

In the absence of systematic studies on the outcome of these programmes, this article aims to offer some thoughts that go beyond mere bibliometric and scientometric evidence, by empirically and comparatively exploring the conditions for, and experiences of research and international collaboration after graduation among Mozambican and Tanzanian beneficiaries. This involves identifying their current positions (geographically and academically), the resources at their disposal for research after graduation (in terms of time and funding), and patterns and experiences

1 Swedish International Development Cooperation Agency 
of international mobility and research collaboration. It is also important to discuss research results critically, both in relation to the policy framework of research partnership programmes and to previous research on institutional conditions for research in low-income African countries. The results are also discussed in the light of previous research on post-colonial knowledge relations. The field of 'post-colonial knowledge relations' has made an important contribution to the way in which contemporary knowledge relations and conditions for research can be theoretically conceptualised (Spivak I990; Hountondji 2002, Harding 2009, Migniolo 20I2). Building on this research, the article will make a contribution to the field by providing empirical research in the social sciences.

The specific research questions that are dealt with are: what are the premises for research in terms of finance and time for the selected group of $\mathrm{PhD}$ graduates? What are their patterns and experiences of international mobility and research collaboration? How can the answers to these questions be understood, in relation to the policy framework of the partnership programme, and in relation to previous research from a post-colonial perspective on institutional conditions for research in low-income African countries?

The article is structured as follows. First, some general background is provided in terms of the role of highly skilled individuals ( $\mathrm{PhD}$ graduates) and the state of international research on mobility and international collaboration. This is followed by an overview of the institutional regime of international development cooperation, explicitly in the area of support for research capacity building, which will be framed within theoretical conceptions on institutional and postcolonial theory, examining Global North and South relations. This part will be supplemented by brief insights into current developments within the global science regime and national policy priorities in higher education and research. The next part outlines the methodology and the sample, followed by empirical findings. Conclusions and policy recommendations are provided at the end.

\section{Swedish Development Cooperation for Research Capacity Building in Low-Income Countries}

Several international development partners have a long record of supporting capacity building at research institutions in Africa, but there are significant differences among them in terms of scope, design and ownership, arising from different views on institutional capacity building (Velho 2004 ; Jones et al. 2007). Swedish development cooperation has supported research capacity building in low-income countries for more than 40 years. The principal rationale behind this support is that each country should have at least one university capable of being a resource for the establishment 
and expansion of national research and higher education (Sida 2006). For this to materialise, the Swedish support is comprehensive: support to individual research projects is an integral part of a wider support effort to the national research system, with provisions for institutions and facilities such as research councils, research policies, administrative resources, libraries and laboratories. The training of $\mathrm{PhD}$ graduates constitutes a core component in keeping with this approach. Over the years, the modality for support has remained relatively unchanged, based on the basic principle that each country should be able to identify its own areas of research and have the capacity to carry out that research.

Since the early I970s, the ability to engage, and take active part in international research collaboration has been clearly highlighted in the Swedish conceptual framework of research capacity (SAREC ${ }^{2}$ I977: I0; I986: II; I992: IO; Swedish Government 20I0: I2; 20I4: 2). The conceptual understanding of research capacity has largely been built around a linear assumption of progression from knowledge production to societal application, development and eventually poverty reduction (Velho 2004).

As mentioned above, a core activity in the Swedish approach has been the training of PhD graduates using a research partnership model (the 'sandwich model'), also designed to counteract brain drain: 'A major intention of the "sandwich model" is that the successful candidate will continue to stay in his home institution after graduation, researching in an environment with a much improved research infrastructure as a result of the support provided by SAREC over the years' (Bhagavan I992: 2I). This approach, which provides operative policy guidance, is believed to promote capacity building efforts more holistically, moving beyond the individual researcher, by gradually transferring responsibilities, administratively and substantively, from the Swedish counterpart to the partner in the collaborating country.

Relational premises between Swedish and collaborating institutions in the Global South have rarely been dealt with in policy documents governing the support for bilateral research collaboration. One of the most profound thoughts on this could be found in an early policy document:

'Limitation processes and lack of development relevance together with dominant political and economic forces have generated a tremendously powerful transnational intelligence industry, of which the Western research community and many of its branches in the third world are integrated parts. As many other multinationals - it imports raw material, not least from the third world. Huge amounts of raw material in the form of students are processed and transformed into 'intellectual Barbie dolls' and re-exported, thus guaranteeing the suc- 
cessful continuation of centre dominance and mimetic development strategies' (SAREC I977: I4, quoted in Brodén Gyberg 2013: 127).

A more recent formulation on this issue could be found in the Swedish government's policy for research covering the period 20I0-20I4:

'The relationship between Swedish researchers and researchers from developing countries is basically unequal in terms of resources. This is also reflected in an imbalance between researchers and research groups as regards their ability to influence the formulation, implementation and reporting of research. Swedish research support is to be designed in such a way that it helps prevent the development of a superior and an inferior status in this relationship' (Swedish Government 2010: I9).

In the recent government research strategy, the relational condition is reduced to a few vague words: '... promote equal research relationships' (Swedish Government 20I4: 3).

This overview shows that cautionary notes were sounded early on about power imbalances in the collaborative relations between the stakeholders, and that this awareness has been preserved in recent government policies/ strategies, though the phrasing has been toned down. But the model has remained generic and has failed to produce practical guidelines to improve implementation.

Swedish development support for research capacity building dates back to I978 in Mozambique and I977 in Tanzania. Since the late I980s, support in both countries has mainly targeted capacity building through training, in accordance with the research partnership model. Approximately I50-200 individuals have graduated with a PhD in each country (Fellesson and Mählck 20I3; Sida 20I4). Swedish university departments have played a substantial role as partners providing supervision, coursework, research facilities and graduation. According to a 2003 Sida evaluation of the Mozambique programme, however, this intention has not been effectively fulfilled: 'Most of the training programmes under Sida/SAREC cannot be classified as "sandwich" type, since the candidates return only to teach or to do administrative work and not least attend to other job commitments to secure an adequate income. Too little time is spent on research at home' (Sida 2003: 22).

The level of government funding for research is low in both Mozambique and Tanzania, with less than o.I percent of GDP spent on research (UNESCO 20IO). Funding from international development partners and foundations makes up more than 90 percent of the research funding at Eduardo Mondlane University (UEM, Mozambique) and Dar es Salaam University (UDSM, Tanzania), which are the focus of this article. The greater part of these funds goes to research training and infrastructure for 
research (administration, library, ICT, laboratory facilities); only a minor part is set aside as support for individual research projects, distributed internally at the universities or by the national research councils (Sida 2003; 2009; 2010).

\section{Previous Research on International Mobility and International Collaboration a Among African Researchers}

Although many sub-Saharan countries have begun to recognise the importance of investing in science and technology (S\&T), their efforts are countered by many factors: the current trend toward mass higher education, or 'massification' (Altbach 2008); global, policy-driven internationalisation of research and higher education, expressed by the increasing number of private institutions; and the demand from other sectors of society for skilled individuals, leading to a competition for top researchers within the international research community (Teferra and Altbach 2004; Bloom et al. 2005; Mamdani 2007; Teferra and Greijn 2010).

Despite economic growth, expanding higher education sectors and demographic prospects, the great majority of African countries are excluded from international data-collecting initiatives to map academic mobility, which concentrate on researchers in the Global North (Ackers 2005; Auriol 20I0; MORE 20I0; Franzoni et al. 20I2; Appelt et al. 20I5). Existing studies primarily discuss mobility in relation to statistical estimates of student mobility and outflows, excluding the PhD level (UNESCO 2012). ${ }^{3}$ Systematic statistical studies and qualitatively based studies of PhD graduates are virtually non-existent (Tremblay 2009; Fellesson and Mählck 2013). Considering the current state of the African research community, the absence of research on mobility and collaboration is particularly worrying. SubSaharan countries' share of global scientific output is just over I percent (UNESCO 20IO). ${ }^{4}$ This figure correlates with low national expenditure on research in most African countries, which in turn affects access to the most valuable resource for research production-the pool of researchers. ${ }^{5}$ Compared with countries in the Global North, the proportion of research-

\footnotetext{
3 For example, in Project Atlas, a collaborative, data-sharing initiative involving six world regions, only South Africa is a listed partner (Project Atlas 2011).

4 This figure masks significant variations between countries. South Africa accounts for almost half of the scientific articles, followed by Nigeria (11.4 percent) and Kenya (6.6 percent). These three countries alone produce two-thirds of the total scientific output among sub-Saharan countries, which implies a bleak picture of scientific production in other countries (UNESCO 2010).

5 Only South Africa is close to reaching the 1 percent gross domestic expenditure on research and development (GERD)/GDP ratio recommended by UNESCO and the African Union. According to the data, the GERD/GDP ratio in most sub-Saharan countries ranges from 0.1 to 0.4 percent (UNESCO 2010: 280). Measuring the GERD/GDP ratio has proved difficult because of lack of data. Many countries have no record of the share of GDP to R\&D (UNESCO 2010: 280-281). Nigeria and South Africa host the largest absolute number of researchers, but proportionally Botswana, Senegal and Guinea are above or at the same level. What is striking is the significant proportional variation between countries, ranging from 8 researchers per million inhabitants in Niger, to 942 per million inhabitants in Botswana (UNESCO 2010).
} 
ers per million inhabitants in most African countries is exceptionally low. Excluding South Africa, one finds an average of 57.5 researchers per million inhabitants in sub-Saharan countries, compared to an average of 3,656 researchers per million inhabitants in OECD countries (UNESCO 20I0).

Regarding international collaboration-in terms of volume of scientific papers published-a similar picture of uneven distribution emerges. The bulk of research, which is dominated by scientometric studies on networks of co-authorship, centres on global core providers (all in the Global North) of scientific production (Schrum et al. 2007; Abramo et al. 2008; Elsevier's SciVal Analytics/Science Europe 20I3). Despite the fact that African countries share many of the problems associated with global challenges (climate, environment, energy, migration, communicable diseases), subSaharan African countries belong to the periphery of global network research collaboration, as illustrated by scientometric maps. ${ }^{6}$ Studies indicate that researchers from low-income countries are also heavily under-represented in publications grounded in research conducted in these countries (Dahdouh et al. 2003). In Central Africa, about 80 percent of articles are co-written with researchers from outside the region (Boshoff 2009, in Brodén Gyberg 2013).

There is a proven correlation between international research collaboration and scientific productivity (Lee and Bozeman 2005; Mairesse and Turner 2005; Abramo et al. 2008). Generally, the number of collaborating researchers is a strong predictor of productivity and higher average citation rates, and top-cited publications are found among countries with higher international collaboration rates. The role of mobility in this nexus is as yet unclear (Appelt et al. 2015: 5-6).

\section{Mobility and International Collaboration Through the Lens of Institu- tional Development and Global Coloniality}

It is possible to understand patterns of academic mobility and international collaboration with the help of spatial relations of scientific practice and interaction (Jöns 2007). This is because various intersecting formal and informal normative institutions determine the prerequisites for mobility and collaboration in global academic production. However, institutional variations in academic production (concepts, problems and methods) are not fixed or universally true, and instead relate to shifting paradigms (institutional changes) over time (Kuhn I962). The recognition and application of these paradigms take place in a network of nodes, bound together by transactions of resources such as ideas, people, funds

6 In maps showing nodes of international cooperation, based on the logarithm of fractionally counted coauthored papers, including countries with more than 500 papers, only South Africa is included. See http://www.leydesdorff.net/intcoll/intcoll.htm 
and artefacts, among others (Latour 1987). A culture of mobility and collaboration-'spaces-in-motion' in Gregory's (2000) phrase-is intimately linked to this interconnecting process (Gregory 2000; Livingstone 2003).

In this article, we follow this rationale, but argue that the connection between cultures of travel and spatial formations of knowledge is largely determined by the position (rank) of the nodes in the network. The rankings of the nodes not only form understandings of scientific concepts, methods and problems, but also determine the degree of inclusiveness and participation in the interaction.

If institutional development and research capacity building through international development cooperation are construed as a path-dependent process (Libecap I989; Ostrom 2005)-meaning that institutions observed at any point in time are functions of current and historically precedent institutions - how are relational power conditions and positions in the mobility and collaboration of African researchers understood? To what extent are historical and current institutions associated with development cooperation determining the conditions for mobility and collaboration, and how are these played out among African researchers situated on different locations?

Post-colonial theory asserts that independence from colonialism does not mean liberation and that colonial subjects remain morally and intellectually colonised through market-driven economic and technological domination (Fanon 1968; Shaobo 1997; Altbach 2004; Sawyerr 2004). Accordingly, mobility and research collaboration between universities in the Global South and North are largely based on the priorities and needs of the universities that are in the strongest position in terms of economic and academic resources. This inequality in research collaboration takes different forms, but generally includes a transfer of research data to the Global North for publication, with minimal input from partners in the Global South. These types of collaboration can be viewed as semi-colonial, since they mostly benefit researchers from the Global North (Costello and Zumla 2000). This represents a challenge for development partners trying to promote equal terms between partners. Bradley argues that:

'Even the most innovative partnership funding strategies cannot resolve all of the tensions and inequalities that characterise collaborative agenda-setting processes. Using North-South partnerships as a "default" funding modality not only adds an extra layer to agenda negotiations, but also creates a problematic starting point for articulating common research goals' (Bradley 2007: 4-6).

As in the colonial era, the premise behind research capacity development in most African countries is set by asymmetric, long-term dependency 
relations with international development partners.' Preconditions for mobility and collaboration are hence extensively linked to policy agendas of the Global North, which, by their control over resources, exert influence over the power of participating researchers to inform national and international research agendas, and ultimately over their positioning in the international research system.

Also of relevance is the way in which higher education and research have come to be viewed as preconditions for development and positioning in a knowledge-driven society. Alongside a country's macroeconomic incentives and institutional setup, its ICT infrastructure, its national innovation system and the quality of its skilled workforce are major determinants for positioning (European Union 20IO). The position of PhD graduates, who are both products and agents of the knowledge society, is naturally central, not least as a key resource for innovation and innovation systems.

\section{Methodology}

This article builds on a mixed methods approach. It comprises both quantitative and qualitative data, collected to map general patterns/tendencies, as well as actual experiences of academic mobility (Allwood 2004). The methodological approach makes it possible to triangulate findings and validate results (ibid.) Some attention has been devoted to tensions between tendencies revealed by large-scale mapping (questionnaire) and nuances highlighted in the personal stories (in-depth interviews). Furthermore, the methodological design is cross-sectional, containing a retro-perspective approach. This means that respondents are asked to answer questions on their individual mobility histories from the date of entry into the PhD programme up to the present.

The methodological design is inspired by George Marcus' understanding of 'multi-sited ethnography', which is suitable to investigate how people who belong to the same group move between different sites (Marcus I995: I06). By investigating how researchers who graduated from the same type of PhD programmes move and experience different academic workplaces in different geographical locations, we analytically explore the degree of contextuality of transnational academic mobility. The comparative analysis is informed by 'cautious comparativism' (Loomba 2009: 5I8). This means that large patterns of similarity—as well as inconsistencies, ruptures and differences within and between the samples and contexts-are regarded as important results.

The data cover PhD graduates and candidates in Mozambique and Tan-

7 Available statistics on proportions of support for research (S\&T) in individual African countries show that the greater part of research activities at many national universities is funded by external actors, predominantly international development partners and foundations (Jones et al. 2007). 
zania with Sida funding, during the period 1990-2013. The year 1990 is chosen as a starting point because it marks the beginning of major changes associated with commodification, privatisation and massification in African higher education and research systems (GUNI 2008). The total data set consists of 29I individuals (I59 in Mozambique and I32 in Tanzania), mainly traced through alumni lists; registers and supervisors at relevant institutions and departments in Sweden and South Africa ${ }^{8}$; and social and professional networks of graduates in different disciplines.

A web-based questionnaire was sent to all 29I individuals. The response rate was 5 I.6 percent ( 82 individuals) in Mozambique case and 65.9 percent ( 87 individuals) in Tanzania. ${ }^{9}$ Data were processed using SPSS Statistics. From the sample, $38 \mathrm{PhD}$ graduates were strategically selected for in-depth interviews, which were conducted as 'mobility biographies', designed to map and explore researchers' trajectories over time, space and place (Kenway and Fahey 20II). Additional information was gained from 'informant interviews' with staff in strategic positions at university and in government in Mozambique, Tanzania and Sweden.

\section{Results}

The results are presented below in three sections: the first aims to contextualise the conditions governing mobility and collaboration, by displaying the results for two basic factors in research production-funding and time for research. The second and third sections deal with the frequency, features and premises (experience of relational conditions) of international mobility and research collaboration of the selected graduates.

\subsection{Funding and Time for Research as Determinants of International Mobility and Collaboration}

Built into the notion of institutional research capacity building is the assumption that the amount and quality of research activities and collaboration will develop with the gradual expansion of research capacity. The supply of trained researchers is a core premise, but for this capacity to result in increased research activities and output, it needs an enabling and supportive environment. Funding and time for research are crucial components.

Among the respondents who reported having conducted research, 4.3 percent of the Mozambican and 6.I percent of the Tanzanian PhD graduates said they had been funded by the government. International

8 South Africa has also been a partner country for PhD training for the Mozambican PhD students. Still, funding comes from Sweden-Sida)

9 To compare, the response rate for similar studies of European PhD graduates has been much lower (11 percent in the MORE project). 
development partners and foundations seem to be the main providers of funds for research in both countries: II.3 percent in Mozambique and I4.5 percent in Tanzania. Private-sector funding is negligible in both cases, but fees from consultancy outside academia is reportedly a major source of funding. The extent of third-party funding (i.e., neither governmentsource nor international development partner funding) is not covered by the survey; but regardless of funding source, respondents from science, technology, engineering and mathematics (STEM) fields (especially from science and medicine) account for the largest share of recipients (64.5 percent). Own savings cover a significant part of the cost of research (for 56.7 percent of respondents in Mozambique and 44.3 percent in Tanzania).

The great majority of respondents in both countries $(82.4$ percent in Mozambique and 86.7 percent in Tanzania) continued to do research after graduation; but our findings show a remarkably weak correlation between completion of $\mathrm{PhD}$ training and increased research productivity, measured in time allocated to conduct research. ${ }^{10}$ Some 67.3 percent of respondents in Mozambique and 59.5 percent in Tanzania report that the PhD training has not resulted in an extension of time scheduled for research activities. Generally, this has nothing to do with a lack of willingness or engagement to do research, but with the increasingly heavy workload in other duties, such as teaching, supervision and administration:

'I'm aware of the expectations on my role as a trained researcher. Entering into the Sida $\mathrm{PhD}$ programme was of course very personal to me, but I knew that I was part of a bigger plan to create better conditions for research at the university (...) Because of the Sida support we are now quite a few PhD holders at my department, but I have to say that research activities have not increased substantially and this is not because of lack of engagement, we all really want to do research. No, the main reason is the heavy teaching load put on all of us (...) The current situation of mass intake of students and the administrative burden following on this is really working against the building of the research capacity at this university' (Mozambican PhD graduate in Social Science).

The vast majority of respondents in both countries (94.I percent in Mozambique and 93.2 percent in Tanzania) spend 25 percent or less of their time on research (table I), with notable variations between the countries and between scientific disciplines. Graduates in social science and the humanities report spending significantly less time on research than graduates from other disciplines, in particular from medicine and science.

10 It may be self-evident, but in any scientific context and in a capacity building context, as described in this article, time allocated for research, in particular, is a basic prerequisite for the development of successful research. The time factor is involved in all parts of the research process (from formulation and application to implementation and publication). 
Lack of longitudinal data prevents us from doing a quantifiable analysis of the development over time, but during interviews, respondents frequently mentioned a gradual reduction in time for research after graduation.

Table 1. Time for research after graduation, by country and scientific discipline (in percentages)

\begin{tabular}{|l|c|c|c|c|c|c|}
\hline $\begin{array}{l}\text { Discipline/ } \\
\text { Country/ }\end{array}$ & Not at all & $\begin{array}{l}\text { Less than } \\
25 \% \text { of } \\
\text { full-time }\end{array}$ & $\begin{array}{l}25 \% \text { of } \\
\text { full-time }\end{array}$ & $\begin{array}{l}50 \% \text { of } \\
\text { full-time }\end{array}$ & $\begin{array}{l}75 \% \text { of } \\
\text { full-time }\end{array}$ & $\begin{array}{l}\text { Full- } \\
\text { time }\end{array}$ \\
\hline Science MOZ & 3.1 & 34.6 & 52.6 & 7.3 & 1.3 & 1.1 \\
\hline Science TZA & 2.1 & 26.3 & 63.2 & 6.3 & 2.1 & 0 \\
\hline Medicine MOZ & 2.2 & 38.5 & 51.9 & 6.1 & 1.3 & 0 \\
\hline Medicine TZA & 1.4 & 26.3 & 58.1 & 9.4 & 3.3 & 1.5 \\
\hline Social science MOZ & 5.7 & 49.8 & 43.2 & 1.3 & 0 & 0 \\
\hline Social Science TZA & 4.9 & 44.8 & 46.3 & 4 & 0 & 0 \\
\hline Humanities MOZ & 6.4 & 51.3 & 41.2 & 1.1 & 0 & 0 \\
\hline Humanities TZA & 3.1 & 53.7 & 40.6 & 2.6 & 0 & 0 \\
\hline Technology MOZ & 5.2 & 26.3 & 61.3 & 7.2 & 0 & 0 \\
\hline Technology TZA & 3.6 & 34.5 & 55.4 & 5.3 & 1.2 & 0 \\
\hline Agricultural science MOZ & 2.2 & 22.8 & 65.8 & 6.9 & 2.3 & 0 \\
\hline Agricultural science TZA & 2.9 & 23.9 & 67.8 & 5.4 & 0 & 0 \\
\hline
\end{tabular}

Note: $\mathrm{MOZ}=$ Mozambique; $T Z A=$ Tanzania.

UEM and UDSM, two flagship institutions, were originally selected by Sida as offering the best breeding grounds for research. The results of this study reveal instead increasing constraints against the strengthening of their research capacity, such as 'massification'. This in turn seems to be a powerful argument against the basic idea of capacity development through the training of researchers, as promoted by Sida and other development partners. 


\subsection{International Mobility}

The international mobility of researchers, defined as physical mobility from one country to another, is recognised as making a significant contribution to the diffusion and improvement of scientific knowledge, both on a national and a global basis (OECD 20I0). It is also known that highly skilled individuals exhibit particular mobility patterns (Appelt et al. 20I5). ${ }^{\text {II }}$ Still, mobility does not follow on naturally as a function of the position as PhD graduate, but is contingent on geopolitical pre-conditions for international research production, which can determine access to international academic positions, and positioning in the competition to access them. Mobility may also be a factor in the establishment of international research collaboration, since mobility potentially increases researchers' exposure to new research contacts. To some extent, this view is contested by the approach taken by the Swedish development support, which prefers graduates to remain in their home institutions, so as to build up a critical mass of researchers there.

The results of our surveys show a low degree of international mobility. The great majority of $\mathrm{PhD}$ graduates in both countries have remained at the same university since graduation. Among the Mozambican graduates, I4.3 percent have been internationally mobile since graduation. The corresponding figure for Tanzanian graduates is II.I percent. In both countries, graduates in medicine, science and agricultural science report a slightly higher frequency of mobility compared to other disciplines, with social science and the humanities at the bottom of the frequency scale. Because of longitudinal limitations in the data, it has not been possible to deduce variations in the international mobility of PhD graduates from different time periods of graduation; however, the data show a higher frequency of international mobility among graduates from 2000 and later, than from the ig80s and ig9os. 
Table 2. Frequency of international mobility after graduation, by country and scientific discipline (in percentages) ${ }^{12}$

\begin{tabular}{|l|c|c|c|c|c|c|c|}
\hline $\begin{array}{l}\text { Discipline/ } \\
\text { Country/ }\end{array}$ & $\begin{array}{l}\text { No } \\
\text { Frequency }\end{array}$ & 1 time & 2 times & 3 times & 4 times & 5 times & <5 times \\
\hline Science MOZ & 83.4 & 10.3 & 3.3 & 1.7 & 1.3 & 0 & 0 \\
\hline Science TZA & 88.7 & 9.1 & 1.8 & 0 & 0.4 & 0 & 0 \\
\hline Medicine MOZ & 81.9 & 12.7 & 3.4 & 0.5 & 1.5 & 0 & 0 \\
\hline Medicine TZA & 83.3 & 12.4 & 2.1 & 0.4 & 0 & 0.6 & 1.2 \\
\hline Social science MOZ & 88.2 & 7.2 & 2.1 & 1.8 & 0.7 & 0 & 0 \\
\hline Social science TZA & 89.1 & 8.7 & 1.5 & 0 & 0.7 & 0 & 0 \\
\hline Humanities MOZ & 93.4 & 4.5 & 2.1 & 0 & 0 & 0 & 0 \\
\hline Humanities TZA & 96.1 & 3.1 & 0.8 & 0 & 0 & 0 & 0 \\
\hline Technology MOZ & 85.1 & 7.1 & 1.9 & 4.6 & 1.3 & 0 & 0 \\
\hline Technology TZA & 88.4 & 4.7 & 4.2 & 0 & 2.1 & 0 & 0.6 \\
\hline $\begin{array}{l}\text { Agricultural Science } \\
\text { MOZ }\end{array}$ & 83.4 & 9.5 & 1.9 & 1.6 & 0 & 0 & 0.6 \\
\hline $\begin{array}{l}\text { Agricultural science } \\
\text { TZA }\end{array}$ & 84.3 & 10.4 & 3.1 & 1.1 & 1.1 & 0 & 0 \\
\hline
\end{tabular}

Note: $M O Z=$ Mozambique; TZA = Tanzania

Africa and Europe are dominant as the regions of destination for most PhD graduates who report international mobility. Notable variances can be observed at the discipline level: as a destination, Europe is twice as common as Africa among graduates in medicine and science, while the opposite holds true for social science and humanities. Mobility to Latin America applies exclusively to graduates from Mozambique. Despite a growing Asian economic presence in Mozambique and Tanzania (primarily from China and India), mobility to that region is still peripheral, with some notable exceptions in the disciplines of technology and science. 
Table 3. Geographical direction in international mobility since graduation, by country and scientific discipline (\%)

\begin{tabular}{|l|c|c|c|c|c|}
\hline $\begin{array}{l}\text { Scientific discipline/ } \\
\text { Country/Region }\end{array}$ & Africa & Europe & $\begin{array}{l}\text { North } \\
\text { America }\end{array}$ & $\begin{array}{l}\text { Latin } \\
\text { America }\end{array}$ & Asia \\
\hline Medicine TZA & 33.8 & 56.6 & 4.3 & 0 & 5.3 \\
\hline Medicine MOZ & 27.1 & 64.5 & 1.3 & 7.1 & 0 \\
\hline Science TZA & 32.3 & 59.6 & 3.9 & 0 & 4.2 \\
\hline Science MOZ & 23.9 & 66.3 & 1.2 & 7.3 & 1.3 \\
\hline Social science TZA & 54.4 & 38.7 & 3.6 & 0 & 3.3 \\
\hline Social science MOZ & 66.4 & 24.4 & 1.3 & 7.9 & 0 \\
\hline Humanities TZA & 71.3 & 24.2 & 3.3 & 0 & 1.2 \\
\hline Humanities MOZ & 73.2 & 22.1 & 0 & 4.7 & 0 \\
\hline Technology TZA & 43.2 & 44.1 & 5.1 & 0 & 7.6 \\
\hline Technology MOZ & 57.1 & 33.5 & 0 & 5.5 & 3.9 \\
\hline Agricultural science TZA & 52.1 & 43.2 & 3.3 & 0 & 1.4 \\
\hline Agricultural science MOZ & 65.5 & 30.1 & 0 & 4.4 & 0 \\
\hline
\end{tabular}

Note: $\mathrm{MOZ}=$ Mozambique; TZA $=$ Tanzania.

\subsection{International Collaboration: Frequency, Patterns and Premises}

Presumably, limited funding and time for research, along with low international mobility, has affected the graduates' ability to engage in different types of research collaboration. Some 47.3 percent of surveyed graduates in Mozambique and 43.4 percent in Tanzania report some form of collaboration with partners outside their countries. As displayed in table 4, Africa and Europe are very much at the centre of research collaboration, regardless of type; collaboration with partners in North America and Asia is infrequent. Not surprisingly, there is a higher frequency of collaboration with partners in Latin America among the Mozambican PhD graduates. 
Table 4. Type of collaboration, by country and region of collaboration (in percentages)

\begin{tabular}{|l|c|c|c|c|c|}
\hline Type of collaboration/Region/Country & Africa & Europe & $\begin{array}{l}\text { North } \\
\text { America }\end{array}$ & $\begin{array}{l}\text { Latin } \\
\text { America }\end{array}$ & Asia \\
\hline Working on joint publications MOZ & 62.1 & 22.3 & 1.3 & 11.1 & 0 \\
\hline Working on joint publications TZA & 64.5 & 22.6 & 4.1 & 0 & 2.5 \\
\hline $\begin{array}{l}\text { Collaborating at distance on a joint } \\
\text { research project MOZ }\end{array}$ & 69.1 & 25.6 & 5.6 & 3.5 & 0 \\
\hline $\begin{array}{l}\text { Collaborating at distance on a joint } \\
\text { research project TZA }\end{array}$ & 59.8 & 22.4 & 2.2 & 0 & 2.2 \\
\hline Fund-raising collaboration MOZ & 68.8 & 29.4 & 0 & 2.2 & 0 \\
\hline Fund-raising collaboration TZA & 63.2 & 20.6 & 2.5 & 0 & 0 \\
\hline
\end{tabular}

Note: $\mathrm{MOZ}=$ Mozambique; $T Z A=$ Tanzania .

While these figures provide an insight into geographical destinations for mobility and preferred regions for collaboration, they do not provide information on the relational context of the graduates' in this dynamics, hence the need for qualitative data. The specific experiences of the respondents vary with respect to the conditions of international collaboration, but there is a general feeling of relative subordination. Regardless of the type of collaboration, respondents report that they often embark on international collaboration with fewer resources compared to their counterparts-in terms of funding, time and academic merit (publications) - and that this fact determines their position with regard to influence, role and consequently rank in the collaborative relationship, for example in relation to academic output (publications).

The consequences of this imbalance in terms of resources are particularly noticeable in collaboration with partners in Europe and in North America. In these cases, the Mozambican and Tanzanian researchers are more often assigned to a predetermined role in the collaboration project, with little or no opportunity to shape the terms of their own involvement. They are instead invited to accept (or not) a role envisioned for them by the ostensibly more influential (non-African) partners. The following two quotations aptly capture the conditions for research and collaboration expressed by several respondents:

'As an African researcher you have to actively search for collaboration opportunities, they are rarely offered [to] you. We are not on the international radar for research collaboration' (Mozambican PhD graduate in science).

'In some of my international collaboration projects I have not been able to assert much influence. For example, in a project together with 
German and Dutch partners I was invited to be part of an application for funding where my role was already set, I just had to accept. And you say yes. Of course it is flattering to be invited, but sometimes the role and motives are unclear and don't really fit your interest. It makes you wonder about the intentions'(Tanzanian PhD graduate in social science).

The frequently unclear and inferior basis for participation in international collaboration projects awakes feelings among participants of being collaborative hostages - reduced to the status of a kind of 'token presence' in Global North research projects on Africa. Because of more prosperous funding opportunities, many of the projects originate with partners in the Global North, which accordingly places the responsibility and control for the collaborative project with those institutions. Consequently, knowledge of, and access to funding opportunities become an early determinant in the 'pecking order' of the partners involved in the collaboration. The African researchers' lack of insight and access to funding opportunities in the Global North significantly reduce their ability to influence and control the shaping of collaborative research projects. The impression of being a hostage also originates from an awareness of policy-induced requirements of many research funding agencies in Global North countries, to increase internationalisation in higher education and research there. Demonstrating collaboration with an African partner has thus become a reinforcing component of applications for research funding.

'All these endorsements of research collaborations. You sign but you rarely hear from them again. In many cases I have a feeling that there is no genuine interest for collaboration, it's just a formality in application processes' (Tanzanian PhD graduate, dean).

Collaboration for African partners sometimes entails idly waiting for instructions from partners in the Global North. Respondents report that active participation is commonly limited to phases in the process that contain practical tasks such as data collection and field work-for example, bureaucratic procedures for research permits, hiring research assistants to carry out interviews, or collecting samples. Once data collection is completed and research enters the phases of analysis and writing, the respondents' roles become more blurred and peripheral. Responsibility and finalizing activities progressively move to the collaborating institutions in the Global North, on the grounds of greater research capacity, a stronger international position and greater access to international dissemination channels, as justified by collaborating institutions in Sweden, for example.

This situation, which has elements of an autocratic relationship, does not, however, encounter any pronounced opposition among the African $\mathrm{PhD}$ graduates. The interviews show that they actively manage and regulate 
the unequal terms of the collaboration because-given the weak research capacity at their home universities - they see individual advantages to being associated with institutions in the Global North. Many respondents say they are willing to accept what they see as an inferior research position in a collaboration project, for the sake of their individual academic careers. In some cases, the same motivation has been visible in the reluctance of $\mathrm{PhD}$ graduates to transfer their training programmes from institutions in the Global North to institutions in the Global South (which is the basic idea of the capacity-building approach). The basic argument has been that a Swedish PhD degree confers higher status (Fellesson and Mählck 20I3).

\section{Conclusions and Policy Implications}

The long-term external support to raise research qualifications among university staff at UEM and UDSM has not resulted in any notable expansion or intensification of research activities, measured in time and resources (funding) for research, compared to what they were able to do while benefitting from the Sida programmes. According to our analysis, the lack of resources for research after graduation and increasing pressure to teach are the two main impediments. This study is limited to analysing the variables of time and resources (funding) in research production. It does not take account of capacity development efforts of the national research and higher education systems of the two countries in other areas, nor does it address matters of institutional leadership, mission or administrative infrastructure to support a greater focus on research. Still, the results require a reconsideration of the context in which external support for research capacity development operates. Specifically, the holistic view of support for PhD training as a basis for research production needs to be supplemented by a context-specific understanding of the conditions for research after graduation. In that context, this article situates research development and relations in development cooperation within the larger framework of post-colonial knowledge relations (Altbach 2004). From this perspective, the low level of international academic mobility after graduation among Africans needs to be understood as more than a mere consequence of Sida's policy on capacity building, which is based on the premise that postgraduates should return to their home academic departments. It can also be understood from the perspective of how post-colonial power relations inside and outside a nation state are reflected in its institutions and people, and how this creates unequal conditions for international academic mobility and research collaboration (Mohanty 2003). Furthermore, a postcolonial perspective on mobility and research collaboration clarifies the various positions and power relations of the researchers involved. This is an under-researched aspect of actor-network-oriented research. Accord- 
ingly, the researchers' readiness to participate in research collaboration based on unequal conditions can be understood as a strategy that allows a marginalised research population to overcome barriers within the transnational research context (see also Mohanty 2003).

The results of this study do not clarify whether the low level of international mobility is a result of the premise on which the 'sandwich model' is based, of a lack of international opportunities and offers, or of a lack of a general commitment to the idea of building a strong national university. Regardless, low international mobility should not be regarded as unequivocally beneficial to strengthening the research capacity of universities; it also has counterproductive implications, and results in a loss of competencies, experience and contacts. Mobility is an important conduit to expand collaboration networks. It has been suggested that the mobility of researchers is an indicator of their competence and flexibility (MORE 20IO).

Despite long-standing research capacity development at UEM and UDSM, inequality in international collaboration persists, perpetuating the inferior position of African PhD graduates. Essentially, the inequality stems from unequal conditions for research production; these prevent PhD graduates from initiating and leading international collaborative research projects. Our results do not suggest any deliberate intention among partners in the Global North to control and dominate; but they indicate a prevailing, institutionalised post-colonial relationship of knowledge (Hountondji 2002), in which the role of the PhD graduates is that of informants rather than research partners. This illustrates an inherent dilemma for the Swedish development programmes for research. On the one hand, they are altruistically geared to increase the capacity for local knowledge production and international participation, based on needs defined by the partner country; on the other hand, this mission is largely pursued in a context informed by the Global North science regime, and inevitably reproduces institutional structures of superiority and subordination. However, thanks to the longterm support of the programmes, relationships have gradually become normalised. The results also suggest that the policy commitment of the two universities to their educational mission runs counter to research capacity development, which in some instances is even declining. This policy priority represents a major threat to investments made so far by development cooperation to prepare individuals to become researchers.

In conclusion, a process of critical assessment to overcome the determinants of relational order and structure in these programmes is imperative. Furthermore, postdoctoral opportunities, which could provide both mobility and research leave (from teaching), are instrumental to the development of a sustainable research capacity. 


\section{References}

Abramo, G., C. D’Angelo and F. Di Costa (2008). Research collaboration and productivity: is there a correlation? Springer Science. Published online April 2008.

Ackers, L. (2005). Moving people and knowledge: Scientific mobility in the European Union. International Migration, 43:5, 99-131.

Allwood, C.M. (2004). Perspektiv på den kvalitativa idétraditionen [Perspective on the qualitative idea tradition]. In C.M. Allwood (ed.), Perspektiv på kvalitativ metod. Lund: Studentlitteratur.

Altbach, P. (2004). Globalization and the University: Myths and Realities in an Unequal World. Tertiary Education and Management, Io:I, 3-25.

Altbach, P. (2008). The complex roles of universities in the period of globalization. In Global University Network for Innovation, Higher Education in the world: New challenges and emerging roles for human and social development. New York: Palgrave.

Altbach, P. (20I3). The global brain race: robbing developing countries. University World News Global Edition, Issue 268.

Appelt, S. et al (20I5). Which factors influence the international mobility of research scientists? OECD Science, Technology and Industry Working Paper, 20I5/02. Paris: OECD Publishing. http://dx.doi. org/Io.I787/5jsitmrr2233-en

Auriol, L. (20I0). Careers of doctorate holders: employment and mobility patterns. STI Working Paper 2010/4. Paris: OECD Publishing.

Auriol, L., M. Misu and R.A. Freeman (2013). Careers of doctorate holders: analysis of labour market and mobility indicators. OECD Science, Technology and Industry Working Paper, 2013/04. Paris: OECD Publishing. http://dx.doi.org/Io.I787/5k43nxgs289w-en

Bhagavan, M.R. (I992). The SAREC model: institutional cooperation and the strengthening of national research capacity in developing countries. SAREC Report I992:I. Stockholm: Sida.

Bloom, D., D. Canning and K. Chan (2005). Higher Education and Economic Development in Africa. Cambridge, MA: Harvard University Press.

Boshoff, M. 2009. Neo-colonialism and research collaboration in Central Africa. Scientometrics, 8I:2.

Bradley, M (2007). On the agenda: North-South research partnerships and the agenda setting processes. Development in Practice, 8:8.

Brodén Gyberg, V (2013). Aiding Science: Swedish research aid policy 19732008. Linköping: Linköping University.

Commission of the European Communities (2008). Better careers and more mobility: A European partnership for research. Communication from Commission to the Council and the European Parliament.

Conchi, S. and C. Michels (20I4). Scientific mobility-an analysis of 
Germany, Austria, France and Great Britain. Fraunhofer ISI Discussion Papers Innovation Systems and Policy Analysis No. 4I. http:// www.isi.fraunhofer.de/isi-wAssets/docs/p/de/diskpap_innosysteme_ policyanalyse/discussionpaper_4I_20I4.pdf

Connell, R (2007). Southern Theory: The global dynamics of knowledge in social science. Cambridge, Polity Press.

Costello, A. and A. Zumla (2000). Moving to research partnership in developing countries. British Medical Journal, 32I.

Dahdouh Guebas, F., J. Ahimbisibwe et al (2003). Neo-colonial science by the most industrialised upon the least developed countries in peerreview publishing. Scientometrics, 56:3, 329-343.

Elsevier's SciVal Analytics/Science Europe (2013). Comparative Benchmarking of European and US Research Collaboration and Researcher Mobility. http://www.scienceeurope.org/uploads/PublicDocuments AndSpeeches/SE_and_Elsevier_Report_Final.pdf

European Union (2010). Europe 2020: A strategy for smart, sustainable and inclusive growth. Communication from the Commission. Brussels.

Fanon, F. (I986). Black Skin, White Masks. London: Pluto.

Franzoni, C., G. Scellato and P. Stephan (20I2). Patterns of international mobility of researchers: evidence from the GlobSci survey. Paper prepared for the international Schumpeter Society Conference, July, Brisbane, Australia.

Global University Network for Innovation (GUNI) (2008). Higher Education in the World: New challenges and emerging roles for human and social development. New York: Palgrave.

Gregory, D. (2000). Cultures of travel and spatial formations of knowledge. Erdkunde, 54:4, 297-319.

Harding, S. (2009) Post-colonial and feminist philosophies of science and technology: convergences and dissonances. Post-colonial Studies, I2:4, 4OI-42I.

Hoba, P. and A. Marfouk. 20II. Why should we worry about brain drain from Africa? Journal of the European Higher Education Area. Issue 4.

Hountondji, P. (2002). The Struggle for Meaning: Reflections on Philosophy, Culture, and Democracy in Africa. Athens, $\mathrm{OH}$ : Ohio University Center for International Studies.

Jones, N., M. Bailey and M. Lyytikäinen (2007). Research Capacity Strengthening in Africa: Trends, Gaps and Opportunities. A scoping study commissioned by DFID on behalf of IFORD. London: Overseas Development Institute.

Jöns, H. (2007). Transnational mobility and the spaces of knowledge production: a comparison of global patterns, motivations and collabo- 
rations in different academic fields. Social Geography, 2, 97-II4.

Kenway, J. and J. Fahey (20II). Getting emotional about brain mobility. Emotion, Space and Society, 4:3, I87-I94.

Kuhn, T. (I962). The Structure of Scientific Revolutions. Chicago: University of Chicago Press.

Latour, B. (1987). Science in Action: How to follow scientists and engineers through society. Cambridge, MA: Harvard University Press.

Lee, S. and B. Bozeman (2005). The impact of research collaboration on scientific productivity. Social Studies of Science, 35:5, 673-702.

Libecap, G.D. (I989). Contracting for Property Rights. Cambridge: Cambridge University Press.

Livingstone, D.N. (2003). Putting Science in its Place: Geographies of Scientific Knowledge. Chicago: University of Chicago Press.

Loomba, A. (2009). Race and the possibilities of comparative critique. New Literary History, 40:3.

Mairesse, J. and L. Turner (2005). Measurement and explanation of the intensity of co-publication in scientific research: An analysis at the laboratory level. NBER Working Paper No. III72.

Mamdani, M. (2007). Scholars in the Marketplace: The dilemmas of neo-liberal reform at Makerere University 1989-2005. Dakar: Council for Development of Social Science Research in Africa (CODESRIA).

Marcuse, G. (I995). Ethnography in/of the world system: the emergence of multi-sited ethnography. Annual Review of Anthropology, 24, 95-II7.

Migniolo, W. (20г2) Local Histories/Global designs. Coloniality, subaltern knowledges and boarder thinking. Oxford. Princeton University Press.

Mohanty, C.T. (2003). Feminism utan gränser: avkoloniserad teori, praktiserad solidaritet. Stockholm: Tankekraft Förlag.

MORE (2OIO). Study on the mobility patterns and career paths of EU researchers. Final report (deliverable 7), prepared for the Commission Research Directorate C - European Research Area Universities and Researchers.

OECD (200I). International Mobility of Highly Skilled. Paris: OECD.

Ostrom, E. (2005). Understanding Institutional Diversity. Princeton: Princeton University Press.

Project Atlas (20II). Student Mobility and the Internationalization of Higher Education: National policies and strategies from six world regions. Institute of International Education.

SAREC (I977). SAREC's First Year Annual Report 1975/76. Stockholm.

SAREC (I986). SAREC Annual Report 1986/87. Stockholm.

SAREC (I992). SAREC Annual Report 1992/93. Stockholm.

Sawyerr, A. (2004). African universities and the challenge of research capacity development. Journal of Higher Education in Africa, 2:I. 
Schrum, W., J. Genuth and I. Chompalov (2007). Structures of Scientific Collaboration. Massachusetts Institute of Technology.

Seth, S. (2009). Putting knowledge in its place: science, colonialism, and the post-colonial. Post-colonial Studies, I2:4, 373-388.

Shaobo, X. (I997). Rethinking the problem of post-colonialism. New Literary History, 28:I.

Sida (2003). Sida support to the University Eduardo Mondlane, Mozambique. Sida Evaluation 03/35. Department for Research Co-operation.

Sida (2006). Sida/SAREC bilateral research cooperation: lessons learned. Sida evaluation o6/r7. Commissioned by Sida, Secretariat of Evaluation and Internal Audit.

Sida (2009a). Tracing Research Capacities in Viet Nam: Perspectives from Vietnamese researchers, Viet Nam-Swedish research cooperation. Stockholm: Sida.

Sida (2009b). Continued bilateral research cooperation with Tanzania I July 2009-30 June 20I3. Assessment memo, Swedish Embassy in Tanzania.

Sida (2010). Joint evaluation of the Swedish country strategy Tanzania, final report annexes.

Sida (20I4). Tracing Research Capacities in Tanzania: A study of Tanzanian PhD holders within the Tanzanian-Swedish research cooperation. Stockholm: Sida.

Spivak, G.C. (I990). The Post-Colonial Critic: Interviews, strategies and dialogues. London: Routledge.

Swedish Government (2010). Research for Development: Policy for research in Swedish development cooperation 2010-2014 and strategy for Sida's support for research cooperation 2010-2014. Stockholm: Swedish Government Offices.

Swedish Government (20I4). Strategy for research collaboration and research in the development cooperation 20I4-202I. Bilaga till regeringsbeslut 20I4-I2-I8 (UF20I4/80398/UD/USTYR).

Teferra, D. and P. Altbach (2004). African higher education: challenges for the 2Ist century. Higher Education, 47:I, 2I-50.

Teferra, D. and H. Greijn (eds) (2010) Higher Education and Globalization: Challenges, threats and opportunities for Africa. Maastricht: Maastricht University.

Tremblay, K. 2009. Academic mobility and immigration. Journal of Studies in International Education, 9:3, I96-228.

UNESCO (2010). UNESCO Science Report: The current status of science around the world. Paris: UNESCO.

UNESCO (20I2). New patterns in student mobility. UNESCO Institute for statistics. http://www.uis.unesco.org/Education/Documents/ib7- 
24 MÅNS FELLESSON AND PAULA MÄHLCK

student-mobility-africa-2or2-v4-en.pdf

Velho, L. (2004). Research capacity building for development: from old to new assumptions. Science, Technology and Society, 9:2, I7I-207. 